\title{
A INTERAÇÃO ARGUMENTATIVA ENTRE O SUPREMO TRIBUNAL FEDERAL E OUTRAS CORTES ${ }^{1}$ // Aline Oliveira de Santana ${ }^{2}$, Luciana de Oliveira Ramos ${ }^{3}$ e Marco Antonio Loschiavo Leme de Barros ${ }^{4}$
}

\section{Palavras-chave}

Supremo Tribunal Federal / argumentação jurídica / precedentes judiciais / tribunais constitucionais / interação argumentativa

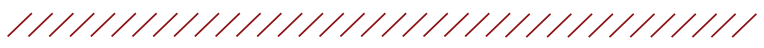

\section{Sumário}

\section{Introdução}

2 Precedente, integridade e interação argumentativa entre cortes no Brasil

2.1 Precedente não é jurisprudência (e viceversa)

2.2 A falta de integridade da jurisprudência e a interação argumentativa entre cortes brasileiras

3 Esquema avaliativo da interação argumentativa

4 Interações argumentativas entre o STF e outras cortes

5 Casos de interação argumentativa

5.1 O caso do crédito-prêmio de IPI

5.2 Conflito de competência entre as justiças comum e do trabalho

5.3 O caso das execuções das contribuições previdenciárias nas condenações trabalhistas

5.4 O caso da ampla defesa em processo administrativo disciplinar

6 Considerações finais

7 Referências

\section{Resumo}

O propósito deste artigo é examinar as interações argumentativas entre o Supremo Tribunal Federal (STF) e outros tribunais com o objetivo de verificar como decisões de outras cortes têm sido utilizadas pelo STF. Utilizando algumas categorias de análise, os autores se propõem a identificar se os ministros do STF se preocupam em construir fundamentações a partir de posicionamentos firmados por outras cortes, inclusive as estrangeiras e transnacionais. A análise qualitativa de alguns acórdãos proferidos em sede de recursos extraordinários revelou fracas interações entre o STF e as outras cortes, porque na maioria dos casos os ministros do STF apenas fizeram menção a decisões anteriores proferidas por outras cortes, sem necessariamente incorporar os argumentos nelas contidos na fundamentação do seu voto. Dos onze casos analisados, em apenas quatro, verificou-se a influência das decisões mencionadas na definição do problema jurídico e da resposta judicial.

1 Esse artigo é fruto dos estudos e pesquisas realizadas pelo Núcleo de Justiça e Constituição da Escola de Direito de São Paulo da Fundação Getúlio Vargas (FGV DIREITO SP), do qual os autores fazem parte. Agradecemos a todos os pesquisadores desse Núcleo pelas profícuas discussões semanais que contribuíram enormemente para as reflexões contidas neste trabalho e pelo apoio da FGV DIREITO SP, em especial à coordenadora do Núcleo, a Professora Luciana Gross Cunha. Agradecemos também os comentários feitos no "Il Seminário Internacional de Teoria Institucional, cortes Institucionais e Realidade Política”, realizado em 2013 na Universidade Federal do Rio de Janeiro (UFRJ), onde uma versão preliminar deste trabalho foi apresentada. Por fim, agradecemos a Susan Hirsch pelas críticas feitas a uma versão mais atualizada do artigo apresentada na Conferência da Law and Society Association, em maio de 2014, em Minneapolis.

2 Mestranda em Direito e Desenvolvimento pela Escola de Direito da Fundação Getúlio Vargas (FGV DIREITO SP) e pesquisadora do Núcleo de Justiça e Constituição da FGV DIREITO SP. E-mail: aline. santana2014@gvmail.br

3 Doutoranda em Direito do Estado pela Faculdade de Direito da Universidade de São Paulo (FDUSP) e mestre em Ciência Política pela Universidade de São Paulo (FFLCH/USP). Professora do GVLaw e pesquisadora do Núcleo de Justiça e Constituição da FGV DIREITO SP. E-mail: luciana.ramos@fgv.br

4 Mestre em Direito e Desenvolvimento pela Escola de Direito da Fundação Getúlio Vargas (FGV DIREITO SP) e pesquisador do Núcleo de Justiça e Constituição da FGV DIREITO SP. E-mail: marcoloschiavo@gmail.com 


\section{ARGUMENTATIVE INTERACTIONS BETWEEN BRAZILIAN SUPREME COURT AND OTHER COURTS // Aline Oliveira de Santana, Luciana de Oliveira Ramos e Marco Antonio Loschiavo Leme de Barros}

\author{
Keywords \\ Brazilian Supreme Court / legal reasoning / pre- \\ cedents / constitutional courts / argumentative \\ interaction
}

HIIIIIIIIIIIIIIIIIIIIIIIIIIIIIIII

\begin{abstract}
This paper examines the argumentative interactions between the Brazilian Supreme Court (Supremo Tribunal Federal - STF) and other courts in order to clarify how the STF uses other court's rulings. Using an analytical framework, the authors sought to identify whether the STF's Justices build their reasoning based on arguments mentioned by other courts' rulings, including foreign and transnational ones. Qualitative analysis revealed weak interactions between the STF and other courts since in most cases Brazilian Supreme Court's Justices merely mention prior rulings, without necessarily discussing the reasoning of other courts' decisions in order to use them as part of its own reasoning. Among the eleven cases analyzed, only in four cases we found some influence of the rulings mentioned in the definition of the legal issue and in the judicial response.
\end{abstract}




\section{Introdução}

No Brasil, um dos elementos que normalmente compõem a fundamentação de uma decisão judicial é a menção a casos decididos anteriormente. A citação de decisões passadas é um importante elemento para a avaliação e para a tomada de decisão judicial em situações idênticas à anterior. Assim, recorrer a decisões passadas é justificável na medida em que casos similares são decididos da mesma maneira.

Vale destacar que a citação de decisões anteriores por magistrados não acontece apenas em relação às decisões já proferidas por eles mesmos ou pelo tribunal do qual são membros. Para além dessas citações, algumas cortes têm mencionado também casos julgados por outros tribunais, sejam eles nacionais, estrangeiros ou até supranacionais.

Além de buscar atender à máxima de que casos similares devem ser decididos de maneira similar, as citações de decisões outras cortes se justificam também em razão do respeito à hierarquia existente na estrutura judiciária brasileira. Vale dizer, os juízes e tribunais ordinários devem observar e respeitar as decisões proferidas por colegiados superiores, cujas função e competência determinam a uniformização da interpretação da lei e conferem maior coerência à ordem jurídica. $^{5}$

Basta verificar que a Constituição brasileira optou, no artigo 92, por distinguir os tribunais superiores dos demais. O Supremo Tribunal Federal (STF), o Superior Tribunal de Justiça (STJ), o Tribunal Superior do Trabalho (TST) e o Tribunal Superior Eleitoral (TSE) exercem, dentre outras funções, a competência recursal que os caracteriza como órgãos julgadores de sobreposição na estrutura judiciária. $\mathrm{Na}$ jurisdição brasileira, são esses os tribunais encarregados de uniformizar a aplicação do direito em todo território, nos termos do artigo $92, \S 2^{\circ}$ da Constituição Federal.

Questão tormentosa que o presente estudo se propõe a analisar é: o que acontece quando os próprios tri-

5 Ressalte-se que se trata de uma definição estabelecida em razão da competência conferida aos tribunais. Não se questionam aqui a autonomia e a independência judicial. O que se destaca é a existência de uma lógica do sistema estruturado a partir de tribunais superiores e pelo duplo grau de jurisdição. bunais superiores estão sendo citados entre si? Essa indagação está relacionada à qualidade da interação argumentativa ${ }^{6}$ estabelecida entre esses tribunais.

Para entender de que modo as decisões de outras cortes superiores estão sendo citadas pelo Supremo Tribunal Federal, o presente artigo visa a examinar as interações argumentativas estabelecidas entre o STF e outros tribunais superiores - nacionais e supranacionais - a partir da citação de julgados. Com isso, pretende-se verificar: (i) qual é o contexto da citação, (ii) quais as repercussões da decisão citada no voto para a argumentação ali desenvolvida e (iii) se existe interação argumentativa entre as cortes.

Cabe esclarecer que a noção de interação argumentativa abordada neste estudo se refere à reflexão e à incorporação dos argumentos abordados na decisão citada seja para confirmá-los, refutá-los ou modificá-los na nova decisão. É dizer, a menção de decisões passadas exige do intérprete o reconhecimento e o aproveitamento do argumento já suscitado para uma nova fundamentação - e não um mero reforço argumentativo. $^{7}$

6 A noção de interação argumentativa para o presente estudo foi inspirada no texto de Virgílio Afonso da Silva, denominado "Integração e diálogo constitucional na América do Sul”. Nesse texto, o autor trabalha com o conceito de integração jurídica e sustenta que ela possui duas formas: a integração jurídica discursiva e a integração institucional-legal. A primeira está relacionada à noção de empréstimo e migração de ideias constitucionais, enquanto a segunda requer instituições e poderes comuns, além de uma jurisdição comum para se concretizar (Silva, 2010). A ideia central apresentada é a possibilidade da integração por meio do diálogo, trata-se de uma integração por meio das ideais constitucionais que ocorre no nível da argumentação horizontalmente entre ordens jurídicas nacionais ou verticalmente entre uma ordem jurídica nacional e uma instância supranacional. Diz o autor: “(...) mesmo que não haja muita legislação comum ou instituições comuns, os tribunais (e os ordenamentos jurídicos como um todo) aproximam-se por meio de uma aproximação no discurso jurídico. A mim me parece ser possível afirmar que isso é integração, uma integração por meio daquilo que alguns autores chamam de discurso entre tribunais, ou seja, de uma conversação ou um diálogo entre tribunais" (Silva, 2010, p. 10). Além disso, como será apontado, no plano teórico, o fundamento para a busca de interações argumentativas decorre da noção dworkiniana de integridade.

$7 \mathrm{Na}$ hipótese de citar decisões passadas como mero reforço argumentativo, a citação de precedentes seria igual ao exercício de exemplificação, apenas esclarecendo e não interagindo de maneira argumentativa. Veja o comentário de Luiz Guilherme Marinoni: "Se o precedente não se presta a permitir a compreensão do presente, mas apenas a indicar como uma situação já foi tratada, 
A interação ocorre a partir das relações entre os tribunais - sejam eles nacionais ou supranacionais-e depende da integração entre eles por meio da argumentação. Como afirma Virgílio Afonso da Silva: “(...) simplesmente conhecer os outros, conhecer suas ideias, discutir e transformar juntos essas ideias podem ser também poderosas formas de integração" (2010, p. 21).

O ponto de partida é o fato que a interação entre as cortes é necessária tendo em vista a contextualização para a argumentação. É por meio da troca de ideias e das experiências que os intérpretes estarão melhor amparados para compreender e enfrentar os problemas da tomada de decisão. E, partindo-se do pressupondo de que efetivamente exista uma comunidade de princípios no sentido dworkinano - que requer que os julgamentos sejam coerentes com tais princípios -, é possível admitir uma integração da jurisprudência atenta a decisões passadas.

O presente artigo parte do diagnóstico da falta de integridade da jurisprudência no sistema jurídico brasileiro ${ }^{8}$ e da confusão entre precedente e jurisprudência. Em que pesem os recentes debates acerca dos institutos de uniformização de jurisprudência, ${ }^{9}$ são poucos os estudos que se preocupam em verificar como ocorre na prática a citação de decisões judiciais e em entender como isso se reflete na dogmática produzida no país. O propósito deste estudo é contribuir para uma melhor compreensão desses fenômenos.

A identificação do modo como ocorrem as citações será realizada por meio do estudo qualitativo das menções feitas ao argumento de outras cortes em acórdãos do STF. Este estudo é, em certo sentido, um

seria possível argumentar a sua assimilação como exemplo" (2010, p. 105).

8 Alguns autores (Streck \& Abboud, 2013; Ramires, 2010) apresentam esse diagnóstico como a fragmentação do sistema jurídico brasileiro. Vale destacar que a falta de integridade da jurisprudência também pode ser identificada aqui como a falta de sistematização das decisões no direito brasileiro (Rodriguez, 2012).

9 Exemplos desses mecanismos de uniformização de jurisprudência são: o julgamento de recursos repetitivos a partir dos artigos 543-B e 543-C do vigente Código de Processo Civil, a introdução da súmula vinculante com a Emenda Constitucional 45/2004 e o debate sobre o projeto de lei do Novo Código de Processo Civil, em especial a atribuição de efeito vinculante para as decisões dos tribunais superiores. desdobramento da pesquisa "Fundamentação e previsibilidade no Supremo Tribunal Federal: um estudo empírico de recursos extraordinários", ${ }^{10}$ realizada em 2012 e 2013 pelo Núcleo de Justiça e Constituição da FGV DIREITO SP com o objetivo de analisar a atuação do STF enquanto corte recursal, função exercida especialmente por meio do julgamento de recursos extraordinários (RE). A hipótese adotada e confirmada pela pesquisa foi a de que as decisões do STF em RE não atendiam a padrões argumentativos suficientes, o que restringia sua previsibilidade. Por sua vez, o termo "previsibilidade" foi entendido como decorrente de uma argumentação capaz de justificar que cada decisão não era tomada casuisticamente. Em outras palavras, tratava-se de verificar se as decisões passadas constrangiam a atuação da corte. A amostra de 53 acórdãos foi determinada a partir dos seguintes critérios: a) recorte temporal entre 05/09/2007 e 01/09/2009, período no qual a composição do STF permaneceu inalterada; b) decisões do plenário, de mérito e efetivamente proferidas em RE.

As indagações deste artigo surgiram da constatação da necessidade de um exame mais profundo das citações de decisões de outros tribunais, incluindo a leitura das decisões citadas, o que escapou ao escopo daquela pesquisa. Para este artigo, portanto, optamos por analisar os 11 recursos extraordinários ${ }^{11}$ pertencentes à amostra supramencionada, nos quais foram identificadas menções a julgados das mais variadas cortes, quais sejam: o Superior Tribunal de Justiça (STJ), o Tribunal Superior Eleitoral (TSE), o Tribunal Superior do Trabalho (TST), o Tribunal Constitucional Alemão, o Tribunal Constitucional da Espanha e a Corte Interamericana de Direitos Humanos (CrIDH).

A análise qualitativa desses casos exemplificativos visa, primeiramente, a identificar as finalidades das citações dos julgados de outras cortes pelos ministros do STF e, em segundo lugar, avaliar se prevalece ou não uma preocupação dos ministros em harmonizar entendimentos ou refletir sobre os posicionamentos firmados por outras cortes.

10 Os resultados da pesquisa foram publicados em livro digital denominado "O Supremo Tribunal Federal para além das Ações Diretas de Inconstitucionalidade" (Cunha, Dimoulis \& Ramos, 2014). 11 Trata-se dos RREE 482.090, 559.943, 556.664, 577.348, 466.343, 568.596, 434.059, 511.961, 597.994 e 596.956 . 
A análise do segundo objetivo conduz à reflexão acerca da importância da interação argumentativa entre as cortes. O objetivo é verificar se existe uma relação entre fortalecimento do ordenamento jurídico, enriquecimento do debate dogmático e a preocupação com a interação das cortes.

Para concretizar essa proposta, o artigo está dividido em seis seções: a primeira corresponde a esta introdução; a segunda contempla o diagnóstico do caso brasileiro que justifica a pergunta central do artigo; na seção 3, é apresentada a metodologia de análise dos casos selecionados; já na seção 4 são explicitados os resultados da análise qualitativa das decisões do STF, examinando-se se há interação entre essa corte e os tribunais federais, os tribunais especiais (TSE e TST) e as cortes estrangeiras e supranacionais. Na sequência, são detalhados os casos em que se verificou interação argumentativa entre as cortes. Por fim, a sexta seção conclui o texto, visando responder à pergunta: por que se preocupar com a interação argumentativa entre as cortes?

\section{Precedente, integridade e interação argumentativa entre cortes no Brasil}

Uma das dificuldades encontradas nas discussões acerca da aplicação de precedentes no Brasil é o descompasso entre o propósito desse instituto, de um lado, e a realidade jurisdicional e o ordenamento jurídico pátrio, de outro.

O precedente é um termo semanticamente vago e ambíguo para o direito brasileiro. ${ }^{12}$ É recorrente verificar na prática que os tribunais acabam, por vezes, aplicando certos institutos (e.g., jurisprudência, precedente, leading case) sem estabelecer critérios capazes de diferenciar esses termos. Aliás, nesse sentido, uma das conclusões da pesquisa "Fundamentação e previsibilidade no Supremo Tribunal Federal: um estudo de recursos extraordinários" foi a constatação da falta de rigor na predicação dos termos pelo STF.

12 É por isso, por exemplo, que expressões como "esta corte já analisou (...)", "a jurisprudência do tribunal firmou-se no sentido (...)" e "orientação firmada por esta corte" podem ser identificadas com facilidade em petições e decisões judiciais, ou mesmo é fácil verificar os grandes blocos de citações de julgados nos acórdãos.
(...) os ministros não tratam o uso da expressão "precedente" de forma rigorosa, apenas seguindo um padrão lexical adotado por outros ministros, já que parece pouco provável que um determinado julgado que esteja na posição especial de precedente seja ignorado pelos demais ministros na decisão de um mesmo caso concreto (Cunha et al., 2014, p. 51-52).

Para o presente estudo, a utilização aleatória (ou sem critérios) desses institutos legais é identificada como sintoma da falta de interação argumentativa entre os tribunais. Isso porque (i) há uma confusão entre precedente e jurisprudência na realidade judicial brasileira e (ii) prevalece uma falta de integridade da jurisprudência produzida no país. A reunião dessas condições gera um paradoxo: as decisões dos tribunais superiores são citadas como autoritativas, mas essa autoridade tem apenas força retórica, pois na prática essas decisões não vinculam as demais instâncias.

\subsection{Precedente não é jurisprudência (e vice- versa)}

Este artigo parte da premissa de que precedente tem um significado distinto de jurisprudência. Isso porque recorrer à força do precedente significa admitir um critério normativo para decisão, em razão de identidade material (fática), a partir de uma dada solução pretérita (e não um conjunto de decisões).

A recíproca é verdadeira, pois a jurisprudência não pode ser identificada como precedente vez que aquela corresponde a uma série reiterada de decisões, baseada na mesma questão jurídica (pouco importando a analogia com a questão fática), cuja função principal é apontar orientações ou, por vezes, sumular os posicionamentos dos tribunais superiores com pretensões de abarcar os casos futuros. 0 termo jurisprudência seria, então, mais adequado no contexto de países cujo sistema jurídico é romano-germânico. É possível afirmar, a respeito desse sistema, que as decisões judiciais têm caráter indicativo ou auxiliar. Em outras palavras, a jurisprudência não tem força vinculante, não é fonte primária de direito (Medina, 2006, p. 117).

Esse caráter auxiliar da jurisprudência deriva, entre outras razões, do fato de a legislação ser a principal 
referência do intérprete do direito no sistema romano-germânico. As regras legisladas, que apresentam uma formulação canônica em termos gerais e abstratos, são desvinculadas dos argumentos favoráveis a elas. Sendo a decisão judicial interpretação e aplicação de uma regra legislada, o recurso a decisões do passado serve, normalmente, para esclarecer o sentido ou a extensão da regra aplicável (Medina, 2006, p. 195-197).

O precedente, por sua vez, é importante instrumento no common law para a compreensão de casos particulares (contextualizados), bem como para afirmar a viabilidade de uma determinada interpretação para uma dada situação particular pretérita. Afinal, "os precedentes são decisões judiciais anteriores que funcionam como modelos para decisões futuras"13 (MacCormick e Summers, 1997, p. 1). Dessa maneira, as regras que decorrem dos precedentes dependem da argumentação que fundamenta a decisão e são extraídas do processo de interpretação, não apresentando formulação canônica.

É por isso que existe a cláusula do stare decisis, a qual impõe ao intérprete verificar a aplicabilidade do precedente ao caso que está sendo decidido. Como o precedente é uma decisão concreta, vinculada ao caso particular, é imprescindível o exame das circunstâncias particulares capazes de justificar ou não a sua aplicação aos casos considerados análogos.

A distinção entre precedente e jurisprudência encontra uma série de divergências na teoria do direito (Dworkin, 2003; Schauer, 2009; MacCormick, 2008), as quais não serão abordadas neste artigo. Contudo, vale ressaltar que o nosso ordenamento jurídico não disciplina o precedente do common law. Em outras palavras, no caso brasileiro, o precedente não é produto da evolução histórica ou resultado da autonomização do sistema, o que impossibilita igualar a experiência brasileira à experiência do common law. ${ }^{14}$

13 Tradução do original: "Precedents are prior decisions that function as models for later decisions".

14 A passagem a seguir esclarece esse ponto: “(...) no common law, a força do precedente reside na tradição, não estando estabelecida em qualquer regra escrita, quer na Constituição e tampouco em regra de ofício. Causa espécie, pois, o estabelecimento, no Brasil, da obrigatoriedade da obediência ao 'precedente sumular' por intermédio de emenda constitucional em um sistema jurídico filiado
Trata-se antes de uma apropriação que repercutiu outros efeitos.

(...) a invocação de precedentes, no Brasil, tem seguindo uma lógica de aleatoriedade que é estranha a qualquer sistema de case law que se conheça, e em especial ao inglês e ao norte-americano. Sequer os rudimentos da teoria de precedentes, destilada durante séculos nos países que têm essa tradição, são conhecidos por aqui. O resultado é um ecletismo improvisado entre duas tradições diversas, sem que haja uma real interlocução entre elas (Ramires, 2010, p. 31).

É possível, no entanto, constatar a aplicação dos precedentes no Brasil. Não se nega aqui o fato de que o sistema jurídico brasileiro é permeável à utilização de precedentes judiciais na fundamentação das decisões. Todavia, é necessário definir e entender em que medida o debate dos precedentes ocorre nos nossos tribunais, verificando o propósito e a viabilidade da aplicação desse instituto como fundamento nas decisões judiciais. Um dos esforços dessa pesquisa é contribuir com esse debate a fim de melhor compreender como decisões pretéritas são utilizadas pelo Judiciário.

É importante destacar que há uma forte tradição de elaborar e prestigiar as ementas com pretensões universalizáveis no Brasil - uma "jurisprudência dos conceitos à brasileira" (Ramires, 2010), que desconsidera o simples fato de a tomada de decisão jurisdicional ser a solução de um problema jurídico particular. Essa é a nossa realidade, "[o]s códigos comentados e os livros de doutrina estão cheios de verbetes jurisprudenciais em tons conceituais, com pretensão de validade universal e, pior, são tomados por universalmente válidos pela comunidade jurídica" (Ramires, 2010, p. 50).

Esta tradição também se faz presente em outros sistemas jurídicos latino-americanos. Medina (2006) observa, em relação ao caso colombiano, uma prática de reduzir as decisões judiciais a pronunciamentos

à família romana-germânica. Por outro lado, lembremos, com Harold Berman, que a regra do stare decisis do common law é fruto de evolução histórica, tal como outros institutos desse sistema jurídico são oriundos de um modelo de procedimento informal, não escrito e livre. Esses institutos e modelos de procedimento existem na mente dos cidadãos e na consciência da comunidade" (Streck, 2013, p. 62). 
quase legislativos por meio de

leituras parciais das decisões, nas quais se decide de maneira mais ou menos arbitrária que partes do texto jurisprudencial podem ser omitidas. Nessa leitura, são eliminados os elementos meramente particulares da decisão (fatos e decisão concreta) na ideia de que se está buscando uma regra canônica de natureza quase-legislativa ou conceitual. Despojados de fatos e decisão, são separados do texto os parágrafos mais gerais e abstratos que pareçam definir o ponto jurídico em questão. A sentença, assim, vale como autoridade de suporte de definições conceituais e não de solução de padrões de fato mais ou menos especificados (Medina, 2006, p. 198)..$^{15}$

A consequência dessa situação, no Brasil, é a posição privilegiada dos tribunais superiores como porta-vozes da produção jurisprudencial, em detrimento daquilo que foi produzido pelos outros tribunais, sobretudo em relação ao debate da questão material, muitas vezes desconsiderada em prol de uma preocupação mais conceitual. ${ }^{16}$ Talvez essa compreensão

15 Tradução do original: "Esta reducción de las sentencias es principalmente alcanzada mediante lecturas parciales de las decisiones, donde se decide de manera más o menos arbitraria que partes del texto jurisprudencial pueden ser obviadas. Por tanto, se eliminan del análisis los elementos meramente particulares de la decisión (hechos y decisión concreta) en la idea de que se está buscando una regla canónica de naturaleza cuasi legislativa o conceptual. Despojados de hechos y decisión, se buscan entre las consideraciones del fallador los párrafos más generales y abstractos que parezcan definir el punto jurídico en cuestión. La sentencia, así, vale como autoridad de soporte de definiciones conceptuales y no de solución de patrones fácticos más o menos especificados". Medina (2006, p. 115-116) chama a atenção para o uso frequente, no direito colombiano, de julgados com base em conexões conceituais: uma sentença é comumente fundamentada com julgados escolhidos não pela semelhança entre os fatos, mas a partir de referências conceituais comuns. A este cenário o autor contrapõe a experiência da Corte Constitucional, que trata suas decisões como precedentes vinculantes e chama as demais Altas Cortes (ConseIho de Estado e Corte Suprema de Justiça) a fazer o mesmo (p.109). 16 Isso pode ser justificado a partir da própria legislação - e não somente em razão da própria conduta do magistrado. Para ilus trar o caso, basta examinar a cláusula de repercussão geral, que funciona como filtro das matérias que chegam ao STF nos recursos extraordinários. Além da transformação da redução da quantidade de processos julgados, a cláusula também implica o distanciamento entre o STF e as instâncias inferiores uma vez que, com base nos artigos 543-A, $§ 5^{\circ}$, e 543-B do Código de Processo Civil, obstaculiza-se a interposição de recursos para a mesma cor- ajude a justificar a frágil interação argumentativa entre cortes brasileiras, já que, como será visto adiante, a grande maioria das citações servem como mero reforço do argumento.

Ao deixar de lado os argumentos apresentados e construídos nas outras instâncias, nota-se um esvaziamento da interação argumentativa entre as cortes. Assim a generalização, por exemplo, das súmulas ou do filtro da repercussão geral podem obstaculizar o processo de interpretação do juiz, impedindo-se, assim, o exame da singularidade do caso jurídico.

Ainda cabe destacar que a posição privilegiada dos tribunais superiores como porta vozes da produção jurisprudencial pode, por vezes, resultar em fator descontrolado de poder, que acaba concentrando a capacidade de decisão em poucos tribunais.

Certamente, uma estrutura organizacional hierarquizada mal compreendida pelos próprios operadores $^{17}$ pode impossibilitar a interação argumentativa apresentada neste trabalho e corroborar com o uso descontextualizado dos julgados, o sincretismo improvisado e as dificuldades decorrentes do mero transplante dos precedentes do common law para a experiência brasileira.

\subsection{A falta de integridade da jurisprudência e a interação argumentativa entre cortes brasileiras}

A ausência de interação entre cortes revela também a falta de integridade da jurisprudência produzida pelos tribunais - já que exclui a tradição das análises e, por vezes, dificulta a uniformização de interpreta-

te em matérias semelhantes. O mesmo efeito de distanciamento pode ser identificado no procedimento de elaboração das súmulas vinculantes, visto que, no longo prazo, elas podem promover o enrijecimento do sistema, pois "ignora[m] que o direito deve ser concretizado em cada caso concreto, e não apenas através da subsunção de fatos a previsões normativas, dessa maneira, passa-se a acreditar que a súmula vinculante, uma vez editada, resolveria diversos casos idênticos, mediante silogismo" (Streck, 2013, p. 51) 17 No Brasil há 27 tribunais estaduais, além de 61 tribunais federais, que englobam inclusive justiças especiais, e tribunais superiores. Nesse sentido, é possível questionar qual seria a finalidade substancial - para além da distribuição de jurisdição - dessa grande ramificação de tribunais no país, sendo que, na prática, as interações argumentativas não acontecem entre as cortes. 
ções já estabelecidas pelos tribunais superiores.

Explicamos: cada juiz está imerso em uma tradição que inclui uma série de histórias e memórias - o que confere ao julgador a necessidade de dialogar com essas decisões, estruturas, convenções e práticas de modo a não cair em arbitrariedades. Aliás, é isso que caracteriza a atividade de interpretar, pois a atribuição de sentidos não ocorre de maneira aleatória e descontextualizada, mas a partir de critérios e contextos previamente conhecidos pelo juiz.

Há uma história que não pode ser negada e, portanto, a pretensão à integridade do direito só pode ser reconhecida a partir da tradição e da memória. Isso exige a abertura para a interação interpretativa. Essa abertura, no entanto, não deve ser caracterizada por uma cega obediência, mas deve estar voltada para uma construção próxima e apropriada do caso analisado.

No plano teórico, a ideia de integridade jurisprudencial baseia-se, em grande medida, nas contribuições de Ronald Dworkin. Segundo esse teórico do direito, a interpretação jurídica exige a observação da integridade dos princípios compartilhados por uma comunidade. A integridade é um ideal político que determina a observação por todos dessa base coesa de princípios compartilhados. Nesse sentido há uma obrigatoriedade, no caso do direito, de observar a integridade no julgamento, solicitando dos julgadores a necessidade de fazê-lo de forma coerente com tais princípios.

[o] direito como integridade pede que os juízes admitam, na medida do possível, que o direito é estruturado por um conjunto coerente de princípios sobre a justiça, a equidade e o devido processo legal adjetivo, e pede-lhes que os apliquem nos novos casos que se lhes apresentem, de tal modo que a situação de cada pessoa seja justa e equitativa segundo as mesmas normas. Esse estilo de deliberação judicial respeita a ambição que a integridade assume, a ambição de ser uma comunidade de princípios (Dworkin, 2003, p. 291).

A ideia de interação argumentativa entre os tribunais traduz uma noção de cooperação judicial (própria de uma comunidade), com a intensificação do debate dogmático, fortalecendo a unidade e a interação das diversas cortes que integram o ordenamento jurídico. $\mathrm{E}$, ao mesmo tempo, tal interação favorece a integridade no julgamento ao longo da história, um verdadeiro continuum - "o direito como integridade pede [aos juízes] que continuem interpretando o mesmo material que ele próprio afirma ter interpretado com sucesso" (Dworkin, 2003, p. 273).

As relações entre as cortes devem ser consideradas, do ponto de vista da integridade, como uma relação de rede, própria de um processo de argumentação envolvendo muitos atores, fundada no aprendizado recíproco em detrimento de uma forma hierárquica monolítica de decidir e atenta ao modelo de comunidade.

Nesse modelo, deve-se verificar uma preocupação das cortes de se colocarem umas nos lugares das outras, para compreender os posicionamentos alheios, não como instâncias estáticas, mas interpretadas no contexto de continuação de uma obra produzida conjuntamente. Aqui não se parte de uma suposta jurisprudência mais autorizada ou principal, mas do debate construído a partir das questões levadas ao Judiciário.

Importa, assim, verificar se na interação argumentativa entre as cortes, por exemplo, os julgados são invocados nos votos não só como obiter dicta, ${ }^{18}$ mas como elementos construtores da ratio decidendi. ${ }^{19}$ É nesse sentido que o precedente judicial adquire papel decisivo na tarefa da continuidade da tradição e da integridade do direito. Sua influência será tão mais forte quanto maior for o debate do enunciado jurídico que decidiu o caso, tanto internamente entre os ministros, como externamente entre as cortes. ${ }^{20}$

Todavia, esse não é o caso da jurisdição brasileira. Sundfeld e Motta Pinto (2012), por exemplo, observam que não há uma síntese orgânica da própria jurisprudência do STF, de modo que não há conheci-

18 Obiter dicta corresponde aos componentes marginais que circundam o argumento central. São os argumentos que não transcendem o caso concreto, tampouco alcançam casos futuros.

19 Ratio decidendi, para os fins deste artigo, corresponde aos fundamentos definitivos para decidir e refere-se à prescrição que pode ser aplicada a casos futuros.

20 Aliás, a ratio decidendi não pode ser considerada isoladamente, pois a regra jurídica utilizada pela Corte somente pode ser analisada em correspondência com a questão material que ela solucionou. 
mento suficiente sobre o quê e o quanto foi decidido e fundamentado pela corte. Segundo os autores, dessa situação decorre um efeito pernicioso: a jurisprudência"21 "não é fator influente na determinação do resultado e das razões respectivas do novo julgamento" (Sundfeld \& Motta Pinto, 2012, p. 29). Isso está relacionado à tendência verificada entre os ministros de confirmar os julgados que citam, seja do próprio STF seja de outras cortes, ${ }^{22}$ que pode ser explicada pelo fato de que:

o conjunto da jurisprudência não [é] tomado como dado a ser necessariamente considerado independentemente do resultado que o voto venha a defender, inclusive para eventualmente superá-lo, mas como um dos vários elementos que podem ser utilizados para a defesa de um resultado, a depender de sua conveniência (Sundfeld \& Motta Pinto, 2012, p. 31).

É a partir desse diagnóstico que o presente artigo busca compreender como a jurisprudência de outras cortes é incorporada às decisões do STF.

\section{Esquema avaliativo da interação argumentativa}

Para alcançar os objetivos propostos neste artigo, foram analisados casos exemplificativos que contemplam citações de julgados de outras cortes superiores pelo STF.

Numa primeira etapa, procurou-se averiguar o papel da citação no argumento desenvolvido no acórdão do STF e fazer uma comparação entre o acórdão do STF e o inteiro teor da decisão citada. Verificamos se havia semelhanças entre o problema jurídico (aqui entendido como caso concreto ou norma cuja constitucionalidade está sendo questionada) enfrentado

21 Os autores entendem por jurisprudência o conjunto integral das decisões de determinado tribunal.

22 Pesquisa realizada pela Sociedade Brasileira de Direito Público - SBDP (Sundfeld \& Souza, 2012, p. 89) constatou, a partir de uma amostra de 267 acórdãos de ações de controle concentrado, que $94 \%$ das citações tinham por objetivo confirmar o posicionamento atribuído ao julgado citado. A pesquisa encontrou um percentual baixo de citações de outras cortes: apenas $2.62 \%$ de todos os precedentes citados (p. 30). pelas duas cortes. Formulamos, então, as seguintes categorias:

A. se o ministro do STF argumenta pelo acerto do julgado citado e ambas as decisões versam sobre o mesmo problema jurídico, o julgado é confirmado;

B. se o ministro do STF argumenta que o julgado citado está equivocado e ambas as decisões versam sobre o mesmo problema jurídico, o julgado é superado;

C. se o ministro do STF argumenta que as decisões versam sobre problemas jurídicos distintos e então descarta o uso do julgado, o julgado é afastado; ${ }^{23}$

D. se o ministro do STF argumenta pelo acerto do julgado citado sem descartar seu uso, mesmo que as decisões não versem sobre o mesmo problema jurídico, o julgado é confirmado por conexão conceitual. $^{24}$

Esta última categoria surge da constatação de alguns ministros podem utilizar argumentos de um julgado cujo caso concreto seja diferente do caso por julgar. Em tais casos, Medina (2006, p. 117) alerta para a possibilidade de gerar decisões ilegítimas, pois a corte pode deixar de utilizar julgados sobre casos semelhantes para decidir somente com base em julgados de referência conceitual comum.

Em seguida, procuramos qualificar esses usos de julgado como inseridos num contexto de interação ou não entre as cortes, acrescentando à análise da primeira etapa considerações sobre como o ministro justifica a citação.

Denominamos casos de interação as situações em que o ministro do STF desenvolve uma justificativa cuidadosa do uso da decisão passada, explicando por que a decisão é relevante e de que modo ela é útil seja para

23 Cf. classificação adotada na pesquisa "O Supremo Tribunal Federal para além das Ações Diretas de Inconstitucionalidade" (Cunha, Dimoulis \& Ramos, 2014) e no artigo "Accountability e jurisprudência do STF: Estudo empírico de variáveis institucionais e estrutura das decisões" (Sundfeld \& Souza, 2012).

24 Nos casos examinados neste artigo, não foram encontradas situações em que o ministro argumentasse que um julgado estivesse equivocado e este versasse sobre um problema jurídico diferente do enfrentado pelo STF. 
definir o próprio problema jurídico que o STF deve resolver, seja para incorporar seus argumentos à argumentação desenvolvida pelo próprio ministro para declarar procedente ou improcedente a ação.

Finalmente, denominamos casos de ausência de interação [ou interações frágeis] as situações nas quais a decisão anterior é mencionada em meio a uma diversidade de elementos, como doutrina ou outros julgados. Cada um dos elementos não é decisivo para a argumentação desenvolvida pelo ministro: sua força decorre da quantidade de elementos que convirjam para o resultado desejado pelo ministro. Outra situa- ção de ausência de interação é aquela na qual a decisão anterior é mencionada enquanto entendimento de uma corte hierarquicamente inferior, a qual tem o dever de mudar de posicionamento e se harmonizar com a posição adotada pelo STF.

\section{Interações argumentativas entre o STF e outras cortes}

Explicitadas as categorias de análise, convém apresentar os resultados da análise qualitativa, reunidos na tabela a seguir:

Tabela 1. Resultados sobre a existência ou não de interação argumentativa entre cortes

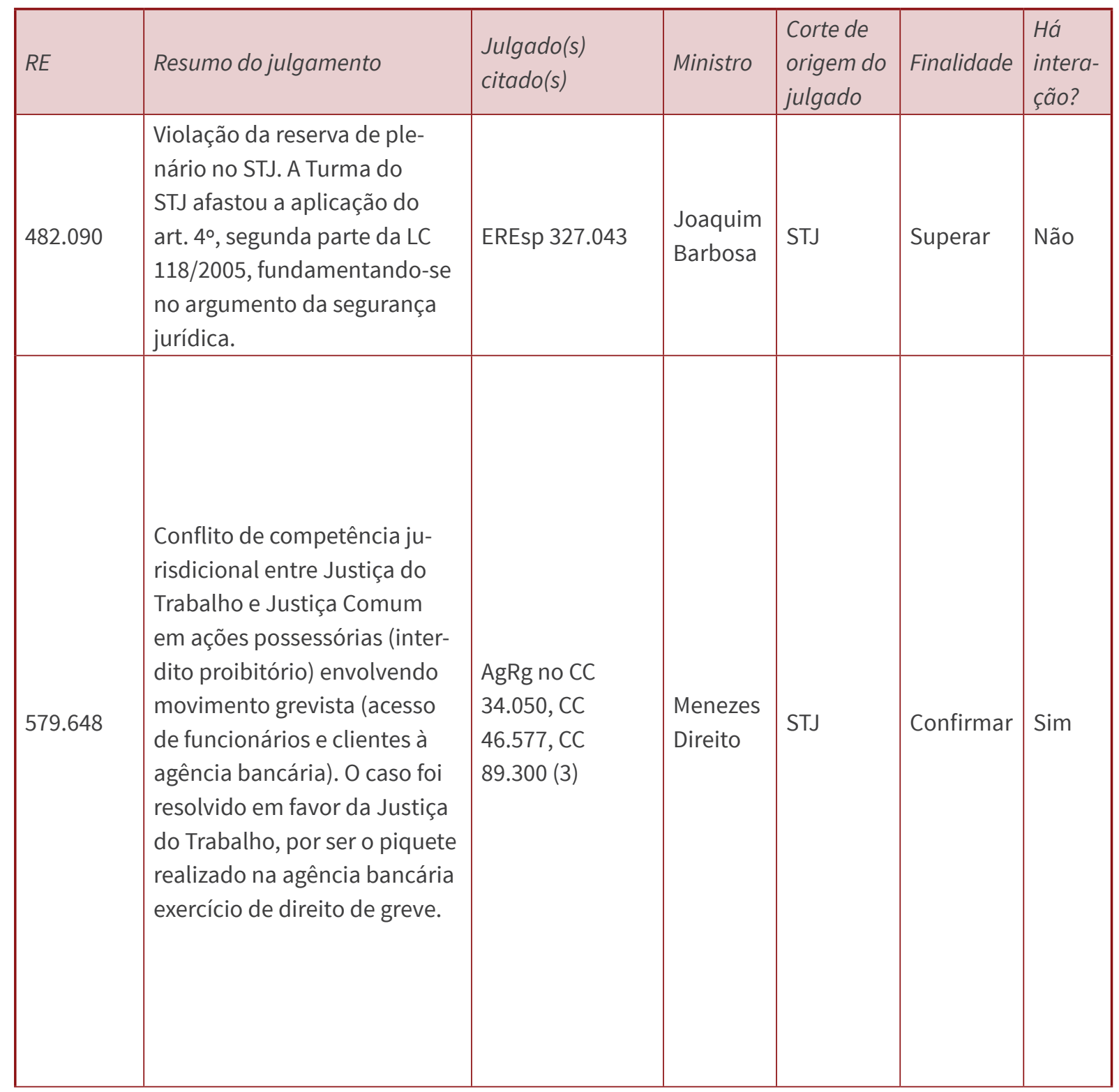




\begin{tabular}{|c|c|c|c|c|c|c|}
\hline 559.943 & $\begin{array}{l}\text { Prazos de prescrição e de- } \\
\text { cadência das contribuições } \\
\text { sociais. Declarou-se a inconsti- } \\
\text { tucionalidade dos artigos } 45 \text { e } \\
46 \text { da lei no } 8.212 / 91 \text { (prazos de } \\
\text { prescrição e decadência maio- } \\
\text { res que os previstos no CTN } \\
\text { para as contribuições sociais) } \\
\text { e do } \S \text { único do artigo } 5^{\circ} \text { do } \\
\text { decreto-lei no } 1.569 / 77 \text { (hipó- } \\
\text { tese de suspensão do prazo } \\
\text { prescricional) por violarem a } \\
\text { reserva de lei complementar. } \\
\text { Os prazos compõem o núcleo } \\
\text { normativo dos institutos da } \\
\text { prescrição e da decadência, de } \\
\text { modo que devem ser regula- } \\
\text { dos por lei complementar nos } \\
\text { termos do artigo } 146 \text { da CF. }\end{array}$ & $\begin{array}{l}\text { Al no REsp } \\
616.348\end{array}$ & $\begin{array}{l}\text { Gilmar } \\
\text { Mendes } \\
\text { e Celso } \\
\text { de Mello }\end{array}$ & STJ & Confirmar & Não \\
\hline 556.664 & $\begin{array}{l}\text { Prazos de prescrição e de- } \\
\text { cadência das contribuições } \\
\text { sociais. Declarou-se a inconsti- } \\
\text { tucionalidade dos artigos } 45 \text { e } \\
46 \text { da lei ñ } 8.212 / 91 \text { (prazos de } \\
\text { prescrição e decadência maio- } \\
\text { res que os previstos no CTN } \\
\text { para as contribuições sociais) } \\
\text { e do § único do artigo } 5^{\circ} \text { do } \\
\text { decreto-lei no } 1.569 / 77 \text { (hipó- } \\
\text { tese de suspensão do prazo } \\
\text { prescricional) por violarem a } \\
\text { reserva de lei complementar. } \\
\text { Os prazos compõem o núcleo } \\
\text { normativo dos institutos da } \\
\text { prescrição e da decadência, de } \\
\text { modo que devem ser regula- } \\
\text { dos por lei complementar nos } \\
\text { termos do artigo } 146 \text { da CF. }\end{array}$ & $\begin{array}{l}\text { Al no REsp } \\
616.348\end{array}$ & $\begin{array}{l}\text { Gilmar } \\
\text { Mendes } \\
\text { e Celso } \\
\text { de Mello }\end{array}$ & STJ & Confirmar & Não \\
\hline \multirow{3}{*}{577.348} & \multirow{3}{*}{$\begin{array}{l}\text { Vigência do crédito-prêmio do } \\
\text { IPI, instituído pelo Decreto-Lei } \\
\text { 491/1969. O STF determinou a } \\
\text { perda da sua vigência, por se } \\
\text { tratar de um incentivo setorial } \\
\text { nos termos do art. } 41, \S 1^{\circ} \text { do } \\
\text { ADCT, aplicável ao setor de } \\
\text { exportações. }\end{array}$} & $\begin{array}{l}\text { AgRg no REsp } \\
329.354\end{array}$ & $\begin{array}{l}\text { Ricardo } \\
\text { Lewan- } \\
\text { dowski }\end{array}$ & STJ & Superar & Sim \\
\hline & & $\begin{array}{l}\text { REsp 541.239, } \\
\text { REsp 652.379, } \\
\text { REsp 765.134, } \\
\text { REsp 739.689, } \\
\text { AgRg nos EREsp } \\
771.219 \text { (5) }\end{array}$ & $\begin{array}{l}\text { Ricardo } \\
\text { Lewan- } \\
\text { dowski }\end{array}$ & STJ & Confirmar & Sim \\
\hline & & REsp 591.708 & $\begin{array}{l}\text { Ellen } \\
\text { Gracie }\end{array}$ & STJ & Confirmar & Não \\
\hline
\end{tabular}




\begin{tabular}{|c|c|c|c|c|c|c|}
\hline \multirow{4}{*}{466.343} & \multirow{4}{*}{$\begin{array}{l}\text { Prisão civil do depositário infiel. } \\
\text { O STF, com base na tese da } \\
\text { supralegalidade dos tratados } \\
\text { internacionais de direitos hu- } \\
\text { manos, declarou a inconstitu- } \\
\text { cionalidade desse tipo de prisão } \\
\text { pautada na aplicação do Pacto } \\
\text { de São José da Costa Rica. }\end{array}$} & \begin{tabular}{|l} 
REsp 7.943, \\
REsp 2.320, \\
REsp 14.938, \\
RMS 995, Resp \\
39.546, HC 2.155, \\
RHC 4.329, RHC \\
3998, HC 2.771, \\
HC 3.206, RHC \\
4.288, RHC \\
4.319, HC 3.294, \\
HC 3.545, RHC \\
4.210, RHC 8.494 \\
$(16)$ \\
\end{tabular} & $\begin{array}{l}\text { Gilmar } \\
\text { Mendes }\end{array}$ & STJ & Confirmar & Não \\
\hline & & $\begin{array}{l}\text { Caso Maastricht } \\
\text { na Espanha }\end{array}$ & $\begin{array}{l}\text { Gilmar } \\
\text { Mendes }\end{array}$ & $\begin{array}{l}\text { Tribunal } \\
\text { Constitu- } \\
\text { cional da } \\
\text { Espanha }\end{array}$ & Confirmar & Não \\
\hline & & \begin{tabular}{|l|} 
Caso Maastricht \\
na Alemanha \\
(BVerfGE 89, 155, \\
175) \\
\end{tabular} & $\begin{array}{l}\text { Gilmar } \\
\text { Mendes }\end{array}$ & $\begin{array}{l}\text { Tribunal } \\
\text { Consti- } \\
\text { tucional } \\
\text { Alemão }\end{array}$ & Confirmar & Não \\
\hline & & \begin{tabular}{|l} 
BVerfGE, 39: \\
210(230-1), BVer- \\
fGE 28, 243 (26), \\
BVerfGE 25, 112 \\
(117), BVerfGE \\
31,229 (240), \\
BVerfGE 37, 132 \\
$(140)$, BVerfGE \\
50, 290 (340), \\
BVerfGE 42, 263 \\
(294), BVerfGE \\
31, 229 (240), \\
BVerfGE 37, 132 \\
(140), BVerfGE \\
50, 290 (339), \\
BVerfGE 52, \\
1(26),BVerfGE \\
71, 230 (247) (12)
\end{tabular} & $\begin{array}{l}\text { Gilmar } \\
\text { Mendes }\end{array}$ & $\begin{array}{l}\text { Tribunal } \\
\text { Consti- } \\
\text { tucional } \\
\text { Alemão }\end{array}$ & $\begin{array}{l}\text { Confirmar } \\
\text { conceitu- } \\
\text { almente }\end{array}$ & Não \\
\hline
\end{tabular}




\begin{tabular}{|c|c|c|c|c|c|c|}
\hline \multirow{4}{*}{568.596} & \multirow{4}{*}{$\begin{array}{l}\text { Critérios de elegibilidade para } \\
\text { as eleições municipais. O STF } \\
\text { determinou não ser elegível } \\
\text { para o cargo de vereadora a } \\
\text { ex-cônjuge de prefeito ree- } \\
\text { leito, dele separada após o } \\
\text { início do segundo mandato. } \\
\text { Para efeitos de elegibilidade, } \\
\text { o vínculo entre os dois per- } \\
\text { manece até o fim do segundo } \\
\text { mandato. }\end{array}$} & Res. 21.775 & $\begin{array}{l}\text { Ricardo } \\
\text { Lewan- } \\
\text { dowski }\end{array}$ & TSE & $\begin{array}{l}\text { Confirmar } \\
\text { conceitu- } \\
\text { almente } \\
\end{array}$ & Não \\
\hline & & $\begin{array}{l}\text { AgR no Al 7.194, } \\
\text { REspE 21.727, } \\
\text { REspE } 22.900\end{array}$ & $\begin{array}{l}\text { Ricardo } \\
\text { Lewan- } \\
\text { dowski }\end{array}$ & TSE & Confirmar & Não \\
\hline & & Res. 22.729 & $\begin{array}{l}\text { Ricardo } \\
\text { Lewan- } \\
\text { dowski }\end{array}$ & TSE & Afastar & Não \\
\hline & & REspE 29.267 & $\begin{array}{l}\text { Carlos } \\
\text { Britto }\end{array}$ & TSE & $\begin{array}{l}\text { Confirmar } \\
\text { conceitu- } \\
\text { almente } \\
\end{array}$ & Não \\
\hline 434.059 & $\begin{array}{l}\text { Garantias processuais em } \\
\text { processo administrativo dis- } \\
\text { ciplinar. O STF julgou que a } \\
\text { ausência de defesa técnica em } \\
\text { processo administrativo disci- } \\
\text { plinar, por si só, não ofende a } \\
\text { garantia da ampla defesa (art. } \\
5^{\circ}, \text { LV, CF), a qual é composta } \\
\text { pelos seguintes elementos: } \\
\text { direito de informação, direito } \\
\text { à manifestação e direito de } \\
\text { ver seus argumentos conside- } \\
\text { rados. }\end{array}$ & $\begin{array}{l}\text { BVerfGE 70, } \\
\text { BVerfGE } 11\end{array}$ & $\begin{array}{l}\text { Gilmar } \\
\text { Mendes }\end{array}$ & $\begin{array}{l}\text { Tribunal } \\
\text { Consti- } \\
\text { tucional } \\
\text { Alemão }\end{array}$ & $\begin{array}{l}\text { Confirmar } \\
\text { conceitu- } \\
\text { almente }\end{array}$ & Sim \\
\hline 511.961 & $\begin{array}{l}\text { Exigência de diploma uni- } \\
\text { versitário para o exercício } \\
\text { da profissão de jornalista. } \\
\text { Tal exigência foi declarada } \\
\text { inconstitucional pelo STF, } \\
\text { pois considerou que a reserva } \\
\text { legal que limita a liberdade de } \\
\text { profissão deve dizer respeito } \\
\text { a habilidades técnicas. Consi- } \\
\text { derou ainda não haver conhe- } \\
\text { cimento técnico próprio para } \\
\text { o exercício do jornalismo. Não } \\
\text { há danos à coletividade a se- } \\
\text { rem evitados com a proibição, } \\
\text { mas sim uma restrição indevi- } \\
\text { da à liberdade de expressão }\end{array}$ & $\begin{array}{l}\text { Opinião Consul- } \\
\text { tiva OC-5/85 }\end{array}$ & $\begin{array}{l}\text { Gilmar } \\
\text { Mendes }\end{array}$ & $\begin{array}{l}\text { Corte } \\
\text { Interame- } \\
\text { ricana de } \\
\text { Direitos } \\
\text { Humanos }\end{array}$ & Confirmar & Não \\
\hline
\end{tabular}




\begin{tabular}{|c|c|c|c|c|c|c|}
\hline & $\begin{array}{l}\text { Elegibilidade dos membros } \\
\text { do Ministério Público. } 0 \text { artigo }\end{array}$ & RESpE 33.174 & $\begin{array}{l}\text { Eros } \\
\text { Grau }\end{array}$ & TSE & Confirmar & Não \\
\hline 597.994 & $\begin{array}{l}\text { 128, § 5०, II, “e”, na redação } \\
\text { dada pela EC } 45 / 04 \text { deve } \\
\text { ser interpretado de modo a } \\
\text { garantir o direito político de } \\
\text { elegibilidade dos membros } \\
\text { do Ministério Público, consa- } \\
\text { grado pelo artigo } 14, \S 5^{\circ} \text {, da } \\
\text { Constituição. }\end{array}$ & RESpE 33.175 & $\begin{array}{l}\text { Carlos } \\
\text { Britto e } \\
\text { Joaquim } \\
\text { Barbosa }\end{array}$ & TSE & Confirmar & Não \\
\hline 569.956 & $\begin{array}{l}\text { Competência da Justiça do } \\
\text { Trabalho para executar as } \\
\text { contribuições previdenciárias } \\
\text { relativas ao objeto da conde- } \\
\text { nação. A sentença é título exe- } \\
\text { cutivo, de modo que as execu- } \\
\text { ções fora da condenação não } \\
\text { constam do título e, portanto, } \\
\text { não podem ser executadas no } \\
\text { âmbito do mesmo processo. }\end{array}$ & $\begin{array}{l}\text { OJ } 141 \text { (transfor- } \\
\text { mada na súmula } \\
368, \text { I, do TST) }\end{array}$ & $\begin{array}{l}\text { Menezes } \\
\text { Direito }\end{array}$ & TST & $\begin{array}{l}\text { Confirmar } \\
\text { conceitu- } \\
\text { almente }\end{array}$ & Sim \\
\hline
\end{tabular}

Fonte: elaboração própria.

A partir das informações constantes da tabela, destaca-se que dos 11 casos analisados, em apenas quatro (RREE 577.348, 579.348, 569.956 e 434.059) identificou-se a existência de interação entre as cortes envolvidas - esses casos serão detalhados no item 5 deste artigo. No conjunto de casos analisados, foram feitas 56 menções a julgados anteriores. Desse total, apenas 12 citações revelaram algum tipo de interação argumentativa entre os tribunais envolvidos, enquanto a maior parte das citações (44) não expressou qualquer interação entre as cortes.

Além disso, como já mencionado, no conjunto de casos examinados estão relacionadas apenas decisões de cortes superiores (STF, STJ, TST e TSE), cortes estrangeiras (Tribunal Constitucional Alemão e Tribunal Constitucional da Espanha) e cortes internacionais (Corte Interamericana de Direitos Humanos).

No conjunto de casos, a relação entre o STJ e o STF foi a que mais apareceu - foram seis casos no total. Nessa relação verificaram-se dois posicionamentos divergentes entre essas cortes. Nos RREE 482.090 e 579.648, a decisão tomada pelo Supremo Tribunal Federal diverge da decisão tomada pelo Superior Tribunal de Justiça. Em contrapartida, o STF e o STJ se- guiram o mesmo posicionamento nos RREE 559.943 e 556.664 ao definir uma questão semelhante - se a disciplina dos prazos de prescrição e decadência das contribuições sociais é matéria de lei complementar. Nos demais casos de relação entre o STF e o STJ (577.348 e 579.648), detalhados no próximo item, houve interação entre as duas cortes.

A relação entre o STF e o TSE foi verificada em dois casos (RREE 597.994 e 568.596). Em ambos não se constatou a interação entre cortes, uma vez que as citações nos dois casos serviram apenas como elementos de concordância com o argumento desenvolvido. ${ }^{25}$

25 A Justiça Eleitoral, criada em 1932, é um ramo especializado do Judiciário e o seu Tribunal Superior é composto por alguns integrantes dos outros ramos do Judiciário. Integram o TSE três ministros do STF, dois do STJ e dois representantes da classe de juristas. Talvez o que justifique esses resultados obtidos nos RREE 597.994 e 568.596 seja em razão da composição do TSE, pois não é raro que um mesmo magistrado atue sucessivamente na mesma causa, primeiramente ao prolatar uma decisão no TSE e, depois, revendo-a na condição de ministro do STF, ao qual originariamente pertencia. Essa hipótese adveio do fato de que a maioria dos argumentos observados nesses acórdãos baseia-se em decisões do TSE proferidas pelos próprios ministros do STF. No RE 597.994, por exemplo, os ministros Eros Grau, Carlos Ayres Britto e Joaquim Barbosa julgaram a mesma ação duas vezes, como membros de cortes distintas, isto é, como ministro do TSE e outra como ministro do STF. O 
A relação entre o STF e TST, por sua vez, foi identificada em um único acórdão (RE 569.956). Ao analisar este julgado, foi identificada a interação entre a decisão do STF e a decisão do TST. Esse caso será analisado de forma mais detalhada no próximo tópico do artigo, por se tratar de um caso em que houve interação argumentativa.

Por fim, na relação entre o STF e cortes estrangeiras, destaca-se que nos casos analisados neste artigo, alguns ministros do STF citaram julgados do Tribunal Constitucional espanhol e da Corte Constitucional alemã. O exame da interação argumentativa nesse contexto revelou que os julgados de ambas as Cortes são utilizados pelos ministros do STF como elementos confirmadores de seu argumento. Tal fato foi confirmado no RE 434.059, o caso das garantias processuais em processo administrativo disciplinar.

No caso em que se discutiu a constitucionalidade da prisão civil do depositário infiel (RE 466.343), o ministro Gilmar Mendes citou mais de dez decisões do Tribunal Constitucional alemão para reforçar os seus dois argumentos centrais: o primeiro relativo à hierarquia dos tratados internacionais; e o segundo referente ao exame da proporcionalidade da prisão civil do depositário infiel. Tais citações serviram para confirmar o posicionamento do ministro em seu voto.

Em apenas um dos casos analisados, foi feita menção a uma decisão de corte internacional: o RE 511.961, no qual se discutiu a constitucionalidade da

curioso é que ao longo do julgamento esses ministros utilizaram - de maneira repetida - as mesmas razões para fundamentar as suas posições. Veja, por exemplo, que o ministro Eros Grau poupou palavras no seu voto e agregou todo o seu voto vencido no TSE: "Por isso peço vênia à Ministra Ellen Gracie, Ministra-Relatora, para agregar a essa minha manifestação agora - eu não vou lê-la por uma questão de brevidade - as razões do voto que dei no TSE e votar no sentido de dar provimento ao recurso". Para defender posicionamento contrário, o ministro Joaquim Barbosa também se valeu dos seus argumentos citados no TSE, também incorporado no voto do recurso extraordinário. Considerando essa sistemática, é possível indagar se realmente existe no caso um diálogo entre essas corte, uma vez que os ministros recorreram aos seus próprios votos passados, na qualidade de ministros do TSE, para novamente reiterar o entendimento pessoal acerca do assunto. Certamente, é possível confirmar que existe uma preocupação de se atentar a uma coerência individual, em relação aos seus próprios posicionamentos. Porém, o que dizer sobre a relação entre as cortes? exigência de diploma para exercício da profissão de jornalista. O ministro Gilmar Mendes, nesse acórdão, utilizou-se amplamente dos argumentos da Corte Interamericana de Direitos Humanos ( $\mathrm{CrIDH}$ ) explicitados na Opinião Consultiva OC-5/85. ${ }^{26}$

A despeito da extensa transcrição de trechos da Crl$\mathrm{DH}$ no voto do Min. Gilmar Mendes, não é possível afirmar que houve uma efetiva comunicação entre as cortes, uma vez que os argumentos foram meramente incorporados ao discurso do ministro, sem que houvesse qualquer reflexão a respeito da pertinência ou não dos argumentos perante a ordem constitucional brasileira. Além disso, não se pode considerar que houve efetiva comunicação entre o STF e a Crl$\mathrm{DH}$, uma vez que nenhum outro ministro fez, em seu voto, qualquer consideração a respeito da violação à Convenção Americana ou aos entendimentos da Corte e da Comissão Interamericana de Direitos Humanos sobre o tema.

\section{Casos de interação argumentativa}

No presente item, são examinados de maneira mais aprofundada quatro casos em que se verificou algum tipo de interação entre as cortes envolvidas. Os dois primeiros dizem respeito à interação entre o STF e o STJ; o terceiro concerne à interação entre STF e TST, e, por fim, o quarto refere-se à interação estabelecida entre o STF e o Tribunal Constitucional alemão.

\subsection{O caso do crédito-prêmio de IPI}

A questão jurídica do RE 577.348 foi definida pelo então ministro do STJ Teori Zavascki como "daquelas situadas em domínios não muito bem demarcados entre a matéria constitucional (de competência do STF) e infraconstitucional (atribuída ao STJ)". ${ }^{27}$

Para julgar o recurso, o STF foi instado a identificar o termo final de vigência do crédito-prêmio do IPI, instituído pelo artigo $1^{\circ}$ do Decreto-Lei 491/1969. A

26 Foi solicitada à Corte Interamericana uma consulta sobre a interpretação dos artigos 13 e 29 da Convenção Americana de Direitos Humanos (liberdade de expressão) em relação à obrigatoriedade de inscrição em ordem ou conselho profissional de jornalistas (Colegio de Periodistas), mediante a apresentação de título universitário, para o exercício da profissão jornalística.

27 REsp 541.239, p. 101. 
complexidade do assunto se deve à superveniência de uma série de diplomas normativos, do Ato das Disposições Constitucionais Transitórias (ADCT) e de decisões do próprio STF declarando a inconstitucionalidade de parte desses diplomas.

O relator, min. Ricardo Lewandowski, verifica que a questão já foi enfrentada pelo STJ e cita uma série de julgados com o fim de demonstrar a existência de três posições naquele tribunal. A primeira entendia que o crédito-prêmio jamais tinha perdido a vigência. ${ }^{28}$ A partir de 2006, o STJ passou a decidir ora afirmando que o crédito-prêmio havia sido revogado em 30/03/1983 pelo Decreto-Lei $1.658 / 79,{ }^{29}$ ora afirmando que o crédito-prêmio teria sido extinto em 05/10/1990, nos termos do artigo 41 do ADCT, em especial diante de seu caráter setorial. ${ }^{30}$ Finalmente, quando eram demandados créditos referentes a períodos posteriores a 05/10/1990, o STJ negava-lhes provimento, invocando tanto o Decreto-Lei $1.658 / 79^{31}$ quanto o artigo 41 do ADCT. ${ }^{32}$

A confluência de normas constitucionais e infraconstitucionais gerou um problema adicional ao STF: o que era de sua competência decidir acerca da questão? Os ministros Ricardo Lewandowski, Cármen Lúcia, Marco Aurélio, Cezar Peluso, Gilmar Mendes, Eros Grau, Ellen Gracie e Carlos Britto, em debates, discutiram o que poderia ser decidido pelo STF e o que cabia ao STJ resolver. O min. Cezar Peluso propôs a seguinte solução:

Se for tal o entendimento da Corte, esta fixa o seguinte: se não foi extinto antes, terá sido extinto, pelo menos, em 1990, com incidência da norma constitucional; mas bem pode ter sido extinto antes, segundo o entendimento das cortes competentes para decidir

28 AgR no REsp 329.254, citado pelo min. Lewandowski na página 22 (versão eletrônica).

29 REsp 541.239, citado pelo min. Lewandowski na página 22 (versão eletrônica).

30 Ver REsp 652.379.

31 Art. $1^{\circ}$. O estímulo fiscal de que trata o artigo $1^{\circ}$ do Decreto-Lei n० 491, de 5 de março de 1969, será reduzido gradualmente, até sua definitiva extinção. (...) §2 A partir de 1980, o estímulo será reduzido em $5 \%$ a 31 de março, a 30 de junho, a 30 de setembro e a 31 de dezembro, a cada exercício financeiro, até sua total extinção a 30 de junho de 1983.

32 Ver REsp 765.134 essa matéria infraconstitucional (RE 577.348, p. 60).

Logo depois, o min. Ricardo Lewandowski chama a atenção para outro aspecto do problema, que é a existência de decisões do STF declarando a inconstitucionalidade de parte da legislação infraconstitucional concernente ao caso. Nos RREE 186.623, 186.359, 180.828 e 208.260, o STF declarou inconstitucional a competência do Ministro de Estado da Fazenda para reduzir, temporária ou definitivamente, ou extinguir o crédito-prêmio. Manteve, no entanto, a competência do Ministro da Fazenda para aumentar o incentivo. ${ }^{33}$ Ainda, no RE 180.828, o STF declarou inconstitucional a competência do Ministro da Fazenda para reduzir, suspender ou extinguir prazos, formas e condições para fruição dos incentivos fiscais à exportação, mantendo a competência para majorar os incentivos. $^{34}$

Segundo o ministro Lewandowski, é da competência do Supremo interpretar tais decisões, delas extraindo todas as consequências e determinando o seu alcance. A intervenção do min. Lewandowski pode ter sido motivada pela constatação de que, ao examinarem a vigência do crédito-prêmio de IPI antes do STF, os ministros do STJ acabaram interpretando e definindo o alcance das decisões do Supremo.

O primeiro posicionamento do STJ em relação às decisões do STF encontra-se no AgR no REsp 329.254, citado pelo ministro Lewandowski. O relator desse julgado, min. José Delgado, afirma (p. 4) que a declaração de inconstitucionalidade do DL no 1.724/79 tornou sem eficácia a totalidade dos Decretos-Leis n 1.722/79 e 1.658/79 (incluindo, portanto, a extinção do crédito em 1983), pois o primeiro fazia referência a estes últimos.

O ministro Teori Zavascki, ainda membro do STJ, ex-

33 O STF julgou a constitucionalidade do artigo $1^{\circ}$ do Decreto 1724/79: O Ministro de Estado da Fazenda fica autorizado a aumentar ou reduzir, temporária ou definitivamente, ou extinguir, os estímulos fiscais de que tratam os artigos $1^{\circ}$ e $5^{\circ}$ do Decreto-Lei n ${ }^{\circ}$ 491, de 5 de março de 1969.

34 Aqui o dispositivo questionado é o art. 3º, I do Decreto 1894/81: O Ministro da Fazenda fica autorizado, com referência aos incentivos fiscais à exportação, a: I - estabelecer prazo, formas e condições, para sua fruição, bem como reduzi-los, majorá-los, suspendê-los ou extingui-los, em caráter geral ou setorial. 
plica como mudou de posição, passando a entender que as declarações de inconstitucionalidade não produziram qualquer efeito sobre a norma que previu a revogação do incentivo fiscal em 30/03/1983:

Todavia, ao estudar o presente caso, verifiquei que a invocada jurisprudência do STF dizia respeito apenas à inconstitucionalidade das normas de delegação constantes nos Decretos-Leis 1.724/79 e 1.894/81, e não à questão ora em foco, que é a alegada vigência, por prazo indeterminado, do crédito-prêmio instituído pelo DL 491/69. Daí a razão porque, agora, estou votando em sentido diferente, lamentando o equívoco em que incorri quando acompanhei o relator na posição anterior (REsp 541.239, p. 107).

Apresentada a controvérsia instaurada, vale destacar a postura do STF em manter-se dentro de sua competência, o que significa atuar de modo coordenado com o STJ. Essa postura é evidenciada pelos debates entre os ministros.

Nesta decisão, o diálogo ocorre em dois níveis: no uso de julgados do STJ pelo ministro Lewandowski e no uso de julgados do STF pelos ministros do STJ. No primeiro nível, os julgados servem para que o Relator estabeleça qual é o problema jurídico e para que os ministros discutam o que cabe ao STF decidir, em comparação ao que é da competência do STJ. No segundo nível, divergências entre ministros na interpretação de julgados do STF são o motivo de uma relevante mudança na jurisprudência do STJ.

\subsection{Conflito de competência entre as justiças comum e do trabalho}

No RE 579.648, o problema central consistia em saber quem era competente para julgar ações possessórias contra atos de paralisação de agências bancárias causados por grevistas: a justiça comum ou a justiça do trabalho. Trata-se de questão que tanto pode chegar ao STJ, pela via do Conflito de Competência (CC), quanto ao STF, pela aplicação do artigo 114 da Constituição Federal, o qual define a competência da justiça do trabalho. ${ }^{35}$

35 Até a Emenda Constitucional 45/2004, o artigo apresentava a seguinte redação: Art. 114. Compete à Justiça do Trabalho conci-
Ao analisar as decisões proferidas por cada tribunal, constata-se que eles seguem caminhos argumentativos próprios, que os conduzem a decisões opostas. 0 relator do caso no STF, ministro Menezes Direito, procurou confirmar o posicionamento do STJ - último tribunal pelo qual passou antes de chegar ao STF. O ministro citou três julgados do STJ em que se decidiu pela competência da justiça comum.

Em dois dos julgados citados, a questão era decidir se a turbação de posse, pelos empregados, de imóveis dos empregadores - os piquetes realizados em agências bancárias - eram exercício de direito de greve e, portanto, competência da justiça do trabalho. OSTJ decidiu que não se tratava de um caso de direito de greve, cabendo à justiça comum julgar a referida ação possessória. No CC 46.577, o STJ baseou-se no argumento de que "a Justiça Comum analisa, exclusivamente, a hipótese de lesão ao direito de posse do banco autor, não adentrando a questão do direito de posse em si” (p. 4). Já o voto do relator do CC 89.300, vencedor por unanimidade, orientou-se pela ideia de que atos regulados por direitos materiais que não o trabalhista não seriam exercício de direito de greve: "a causa e o pedido são relativos à posse de bens imóveis e sua manutenção, matéria eminentemente de cunho civil” (p. 3).

liar e julgar os dissídios individuais e coletivos entre trabalhadores e empregadores, abrangidos os entes de direito público externo e da administração pública direta e indireta dos Municípios, do Distrito Federal, dos Estados e da União, e, na forma da lei, outras controvérsias decorrentes da relação de trabalho, bem como os litígios que tenham origem no cumprimento de suas próprias sentenças, inclusive coletivas.

Atualmente, após a Emenda, a redação é a seguinte: Art. 114. Compete à Justiça do Trabalho processar e julgar: I - as ações oriundas da relação de trabalho, abrangidos os entes de direito público externo e da administração pública direta e indireta da União, dos Estados, do Distrito Federal e dos Municípios; II - as ações que envolvam exercício do direito de greve; III - as ações sobre representação sindical, entre sindicatos, entre sindicatos e trabalhadores, e entre sindicatos e empregadores; IV - os mandados de segurança, habeas corpus e habeas data, quando o ato questionado envolver matéria sujeita à sua jurisdição; V - os conflitos de competência entre órgãos com jurisdição trabalhista, ressalvado o disposto no art. 102, I, o; VI - as ações de indenização por dano moral ou patrimonial, decorrentes da relação de trabalho; VII - as ações relativas às penalidades administrativas impostas aos empregadores pelos órgãos de fiscalização das relações de trabalho; VIII - a execução, de ofício, das contribuições sociais previstas no art. 195, I, a, e II, e seus acréscimos legais, decorrentes das sentenças que proferir; IX - outras controvérsias decorrentes da relação de trabalho, na forma da lei. 
Finalmente, no AgRg no CC 34.050, relatado pelo próprio ministro Menezes Direito, o argumento decisivo é de que o pedido e a causa de pedir não envolvem matéria trabalhista. Este último julgamento é anterior à Emenda Constitucional 45/2004, que dispôs de maneira expressa que as ações relacionadas ao exercício do direito de greve deveriam ser julgadas pela Justiça do Trabalho.

Votando no RE 579.648, o ministro Menezes Direito advertiu que antes mesmo da EC 45, no entanto, o STF já adotava uma posição oposta à do STJ, interpretando o artigo 114 da Constituição de modo a declarar competente a justiça do trabalho sempre que os conflitos tivessem origem na relação de trabalho, fosse a matéria trabalhista ou outra. ${ }^{36} \mathrm{Em}$ seguida, o ministro argumentou que a turbação do direito de posse não necessariamente decorreria da relação de emprego, pois "em tese, o movimento poderia ser capitaneado por funcionários de outras instituições financeiras, sem nenhuma participação dos empregados do recorrido" (RE 579.648, p. 1544). Por fim, o ministro argumentou que a questão dos autos não envolvia o exercício do direito de greve: "Ainda que se entenda que uma ação que envolve o exercício do direito de greve é toda ação em que se desafiam os limites desse direito, o interdito proibitório não se enquadraria nessa definição, porque o atuar contrário à lei representado pela turbação da posse não faz parte de seu conteúdo" (RE 579.648, p. 1545).

Os demais ministros discordaram, decidindo pela competência da Justiça do Trabalho. Em seus votos, a ministra Carmen Lúcia e o ministro Ricardo Lewandowski argumentaram que o piquete era um ato relativo à greve. 0 ministro Carlos Britto considerou que eventuais atos ilícitos, ou abusos de direito de greve, deveriam ser julgados pela justiça do trabalho. 0 ministro Cezar Peluso reforçou essa argumentação afirmando que não é possível estabelecer uma noção de abuso de direito que seja independente da própria noção de direito.

Em suma, no julgamento do RE 579.648, o ministro Menezes Direito procurou incorporar à sua argumen-

360 ministro cita alguns julgados representativos desta posição do STF: Al 611.670, Al 598.457, CJ nº 6959 e RE 238.737. tação a jurisprudência do STJ, pois fundamentou seu voto levando em conta a existência de posicionamentos opostos no STF e no STJ e utilizando os argumentos subjacentes a cada um deles. O ministro acabou decidindo que o posicionamento do STJ era o mais adequado, determinando, assim, a competência da justiça comum. Nesse contexto, pode-se dizer que houve uma interação entre os tribunais em questão.

\subsection{O caso das execuções das contribuições previdenciárias nas condenações trabalhistas}

A análise do único acórdão do STF em que se verificou uma menção a um julgado do TST revelou uma interação entre essas cortes. O julgamento do RE 569.056 resultou numa preocupação em preservar a autonomia da jurisdição especial da justiça do trabalho, reforçando a jurisprudência já produzida pela corte trabalhista.

A fundamentação do voto do relator, ministro Menezes Direito, no RE 569.056 utiliza a jurisprudência do TST para melhor definir o problema jurídico em questão. $O$ voto do relator contém uma construção histórica de como o TST lidou com a abrangência da interpretação do artigo 114, VIII, da Constituição Federal ao longo dos anos. O relator chega a afirmar que "para a solução da questão posta nos autos, na minha compreensão, é importante compreender o funcionamento da Justiça do Trabalho, especialmente após as reformas que ampliaram sua competência, e a natureza de suas decisões" (RE 569.056, p. 855). 0 problema central do caso em análise era saber se a justiça do trabalho era competente para executar somente as contribuições previdenciárias relativas ao objeto da condenação, ou a contribuições referentes também ao período contratual fora da condenação.

O principal fundamento apresentado foi o de que a execução de uma contribuição social que não foi objeto de decisão não poderia ser executada pela justiça do trabalho, pois além do valor não ser objeto da sentença, não haveria um título executivo. Esse argumento foi determinante para desprover o recurso do INSS, por unanimidade.

O ministro construiu esse argumento a partir de um mapeamento histórico das decisões da justiça do 
trabalho, mostrando como essa corte julgou a execução de contribuições previdenciárias ao longo dos anos. 0 marco inicial identificado pelo ministro foi a Resolução no 125 de 05/04/2005, que aprovou a Súmula no 368 do TST. Nesse momento, o TST entendia que sua competência abrangia também a execução de contribuições sociais fora do período contratual objeto da sentença trabalhista. Em 10/11/2005, foi aprovada a Resolução no 138 , que modificou o inciso I da mesma súmula e estabeleceu a atual orientação. Segundo o ministro Menezes Direito, o modo como o INSS procedia em relação às contribuições motivou a mudança na jurisprudência. A justiça do trabalho executava e o INSS recebia, mas não depositava as contribuições no nome do trabalhador e ao mesmo tempo continuava exigindo dele a prova do tempo de serviço para fins previdenciários. Ou seja, a condenação trabalhista não era suficiente para assegurar ao reclamante a fruição do benefício.

A solução do problema decorreu de entendimento já pacificado anteriormente na justiça do trabalho, inicialmente com a antiga Orientação Jurisprudencial no 141 transformada na Súmula 368 - I do TST. Tal súmula reconhece que a justiça do trabalho é competente para determinar o recolhimento das contribuições previdenciárias, observando-se o limite de valores estabelecido em sentença condenatória.

Nota-se, portanto, que o STF apenas chancelou o entendimento já sumulado pelo TST. Contudo, é preciso reconhecer um esforço no voto do relator em compreender a jurisprudência da outra corte para melhor definir o problema jurídico a ser julgado pelo tribunal a que pertence.

\subsection{O caso da ampla defesa em processo administrativo disciplinar}

No que concerne ao RE 434.059, a menção à decisão de uma corte estrangeira - no caso, o Tribunal Constitucional alemão - também serviu de base para um dos fundamentos centrais apresentados pelo STF. 0 caso em questão discute se a ausência de defesa técnica em processo administrativo disciplinar ofende a garantia da ampla defesa prevista constitucionalmente (art. $5^{\circ}, \mathrm{LV}, \mathrm{CF}$ ).

O STF determinou que, por si só, a ausência de ad- vogado constituído ou de defensor dativo habilitado não implica a nulidade de processo administrativo disciplinar. Segundo o tribunal, apenas haveria ofensa à ampla defesa caso não tivessem sido garantidos os direitos à informação, à manifestação e à consideração dos argumentos manifestados pelo servidor que está sendo processado, o que, segundo os ministros, não ocorreu no caso em análise.

Para sustentar esse posicionamento, o ministro Gilmar Mendes utiliza o argumento de que a Constituição, ao assegurar a ampla defesa em processos judiciais e administrativos disciplinares, pretende garantir uma pretensão à tutela jurídica. Depois de citar doutrinadores brasileiros que reforçam esse argumento, o ministro afirma:

Não é outra a avaliação do tema no direito constitucional comparado. Apreciando o chamado 'Anspruch auf rechtliches Gehör' (pretensão à tutela jurídica) no direito alemão, assinala a Corte Constitucional que essa pretensão envolve não só o direito de manifestação e o direito de informação sobre o objeto do processo, mas também o direito de ver os seus argumentos contemplados pelo órgão incumbido de julgar (cf. Decisão da Corte Constitucional alemã - BverfGE 70, 288-293; ...) (RE 434.059, p. 741).

Em seguida, o ministro destaca que a "pretensão à tutela jurídica", conforme denominado no direito alemão, é composta pelos seguintes elementos: direito de informação, direito à manifestação e o direito de ver seus argumentos considerados. Apresentados esses elementos, examina o sentido de cada um deles com base na doutrina alemã e também menciona uma decisão do Tribunal Constitucional daquele país a fim de explicitar o que se entende por direito de manifestação. Nessa oportunidade, o ministro Gilmar Mendes afirma:

Direito de manifestação (Recht auf Äusserung), que assegura ao defendente a possibilidade de manifestar-se oralmente ou por escrito sobre os elementos fáticos e jurídicos constantes do processo (Cf. Decisão da Corte Constitucional - BverfGE 11, 218 (218) ...) (RE 434.059, p. 742).

No momento em que o ministro aborda o tema da 
pretensão à tutela jurídica, afirma que essa pretensão "corresponde exatamente à garantia consagrada no art. 5 LV da Constituição" (p. 742). Ao comparar a "pretensão à tutela jurídica" ao disposto no art. 5, LV, da Constituição, o ministro parece fazer um esforço no sentido de estabelecer relações entre as regras jurídicas alemãs e brasileiras.

O argumento acerca da explicação da ampla defesa constitui fundamento central na decisão. 0 ministro ressalta que caso tenham sido assegurados os direitos de informação, manifestação e de consideração dos argumentos manifestados, mesmo diante da ausência de defesa técnica em processo administrativo disciplinar, a ampla defesa foi exercida de forma plena. Desse modo, não teria havido violação ao art. $5^{\circ}$, LV, da Constituição Federal.

Ao examinarmos as menções feitas no voto do ministro Gilmar Mendes às decisões do Tribunal Constitucional alemão, verifica-se uma interação argumentativa, porque o ministro buscou em decisões estrangeiras um conceito de ampla defesa para justificar o seu argumento. Na conceituação de Medina (2006), a segunda citação foi feita com o objetivo de utilizar um conceito comum.

\section{Considerações finais}

Este artigo se propôs a examinar como se dá a interação argumentativa entre o STF e outras cortes, a partir da citação de decisões. Com isso, pretendia-se identificar como o STF usa as decisões de tribunais nacionais, estrangeiros ou até supranacionais e avaliar também em que medida isso importa para a dogmática produzida no país.

Em primeiro lugar, cabe esclarecer que a interação entre as cortes pertence ao processo de interpretação ${ }^{37}$ do direito, pois o direito não se encontra

37 Vale destacar que o próprio processo de interpretação não ocorre no vazio ou, em outros termos, sem algum suporte ontológico-linguístico para o intérprete. A interação é inerente à interpretação. $O$ que a virada linguística, no século XX, destacou foi o simples fato de que o intérprete já está inserido num mundo estabelecido de significado e, portanto, é a linguagem que constitui o mundo e a condição de possibilidade de interpretação decorre da atribuição de todo e qualquer sentido dado pelo intérprete a partir apartado da realidade social, tampouco da própria tradição jurídica a que pertence. Nesse sentido, a referência às decisões passadas é necessária tendo em vista o princípio da igualdade, o respeito à hierarquia dos ordenamentos e, sobretudo, como apresentado no estudo, à interação argumentativa.

A interação entre as cortes é importante para contextualizar o caso a ser julgado e para estabelecer relações com outras formas de tomada de decisão, sendo imprescindível na busca pela melhor decisão judicial.

Em segundo lugar, um elemento a ser destacado neste debate é o fato de que a própria interpretação do direito provoca suas dúvidas e hesitações, pois não se trata de um mero raciocínio matemático, mas de um processo de tomada de decisão, envolvendo inúmeras variáveis legais, a comunicação e o intérprete. A referência a decisões pretéritas contribui, em certa medida, para estabelecer certos padrões e auxiliar nos processos de tomada de decisão. Todavia, esses padrões requerem o estabelecimento de critérios pelo julgador.

É por isso que a possibilidade de uma interação a partir de um franco diálogo contribui para a redução de incertezas, pois, afinal, o objetivo almejado por qualquer órgão decisório deveria ser produzir sempre a melhor interpretação possível daquilo que o último julgador entendeu ser a melhor interpretação para o caso.

Considerados esses elementos, o estudo qualitativo dos casos selecionados demonstra que, embora o STF venha citando precedentes de outras cortes tanto nacionais quanto estrangeiras ou supranacionais - verifica-se a existência de frágeis interações com outras cortes.

Dentre as 56 menções a julgados anteriores, apenas 12 revelaram certo nível de interação argumentativa entre o STF e outra corte. Estas menções foram identificadas em 4, dos 11 casos examinados no presente estudo. Trata-se de citações em que o argumento da outra corte, mencionado por um ministro do STF, foi

de suas interações. A atenção deve ocorrer com os preconceitos do intérprete. 
relacionado com argumentos anteriores ou com os que vieram adiante. $\mathrm{O}$ objetivo dessas menções não era meramente reforçar o argumento proferido pelo ministro, mas, de fato, tentar incorporar o argumento na construção de uma resposta ao caso.

Porém, de modo geral, nota-se uma parca comunicação entre as cortes examinadas, porque, na maior parte dos casos, os ministros do STF apenas fazem menção a decisões anteriores proferidas por outras cortes, sem necessariamente incorporar os argumentos nelas contidos na fundamentação do seu voto.

As conclusões deste artigo suscitam novas perguntas relevantes para a melhor compreensão acerca do papel das cortes no Estado democrático de Direito e a interpretação do direito. Por que o STF raramente faz menção a decisões de outros tribunais? Quais são as consequências, para a teoria do direito, de uma fraca comunicação entre cortes? Como explicar essa tradição de frágeis interações argumentativas entre as decisões de tribunais nacionais, internacionais e supranacionais? Seria possível estabelecer uma diferenciação entre precedentes internos a uma ordem jurídica e precedentes ditos globais?

Todas essas indagações merecem atenção da literatura nacional no sentido de se compreender tanto os motivos que levam os tribunais a citar julgados anteriores quanto as razões das fracas relações entre cortes. Assim, mais importante do que os resultados analíticos apresentados, é apontar para as novas perguntas suscitadas por este diagnóstico. Tais perguntas configuram propostas de pesquisas a serem exploradas no sentido de se avaliar a dinâmica das interações argumentativas entre as cortes e de que forma tais interações contribuem para o alcance da melhor prestação da tutela jurisdicional.

HIIIIIIIIIIIIIIIIIIIIIIIIIIIIIIIIII 


\section{Referências}

Cunha, L. G.; Dimoulis, D. \& Ramos, L. (2014). O Supremo Tribunal Federal para além das ações diretas de inconstitucionalidade. São Paulo: Acadêmica livre.

Dworkin, R. (2003). O império do direito (trad. J. L. Camargo). São. Paulo: Martins Fontes.

Dworkin, R. (2002). Levando os direitos a sério (trad. N. Boeira). São Paulo: Martins Fontes.

Klafke, G. F. (2010). Vícios no Processo Decisório do Supremo Tribunal Federal. (monografia). Sociedade Brasileira de Direito Público - SBDP. Disponível em:http://www.sbdp.org.br/arquivos/monografia/164_Monografia\%20Guilherme\%20Klafke.pdf

Maccormick, N. (2008). Retórica e o Estado de Direito (trad. C. H. Mendes). Rio de Janeiro: Elsevier.

Maccormick, N. (2006). Argumentação jurídica e teoria do direito (trad. W. Barcelos). São Paulo: Martins Fontes.

Maccormick, N. \& Summers, R. S. (1997). Interpreting Precedents. Aldershot: Dartmouth.

Marinoni, L. G. (2010). Precedentes obrigatórios. São Paulo: RT.

Medina, D. E. L. (2006). El derecho de los jueces: obligatoriedad del precedente constitucional, analisis de sentencias y líneas jurisprudenciales y teoría del derecho judicial. Bogotá: Legis.

Ramires, M. (2010). Crítica à aplicação de precedentes no direito brasileiro. Porto Alegre: Livraria do Advogado.

Rodriguez, J. R. (2012). Por um Novo Conceito de Segurança Jurídica: Racionalidade Jurisdicional e Estratégias Legislativas. Analisi e Diritto, 129-152.

Schauer, F. (2009). Thinking like a lawyer: a new introduction to legal reasoning. London, Harvard University Press.

Schauer, F. (2008). Why precedent in law (and elsewhere) is not totally (or even substantially) about analogy. KSG Working Paper N. RWP07-036. University of Virginia School of Law. Disponível em: http:// papers.ssrn.com/sol3/papers.cfm?abstract_ id $=1007001$.

Silva, V. A. da (2010). Integração e diálogo constitucional na América do Sul. In A. von Bogdandy; F. Piovesan \& M. M. Antoniazzi (orgs.). Direitos humanos, democracia e integração jurídica na América do Sul. Rio de Janeiro: Lumen Juris.

Sundfeld, C. A. \& Pinto, H. M. (2012). Três Desafios para Melhorar a Jurisdição Constitucional Brasi- leira. In P. Gorzoni; H. M. Pinto; R. P. de Souza \& A. Vojvodic. Jurisdição Constitucional no Brasil. São Paulo: Malheiros.

Sundfeld, C. A. \& Souza, R. P. de (2012). Accountability e jurisprudência do STF: estudo empírico de variáveis institucionais e estrutura das decisões. In P. Gorzoni; H. M. Pinto; R. P. de Souza \& A. Vojvodic. Jurisdição Constitucional no Brasil. São Paulo: Malheiros.

Streck, L. L. \& Abboud, G. (2013). O que é isto - o precedente judicial e as súmulas vinculantes? Porto Alegre: Livraria dos Advogados.

Data de submissão/Submission date: 19.02.2014

Data de aceitação para publicação/Acceptance date: 29.11.2014 